DOI: 10.1515/ausp-2015-0047

\title{
Travelling to the East: A Nonverbal Communication Account
}

\author{
Elena BUJA \\ Transilvania University of Braşov \\ Department of Foreign Languages and Literatures \\ elena_buja@yahoo.com
}

\begin{abstract}
The present paper aims to give some account of the inner life of the East of which a traveller seldom gains more than a passing glimpse, by exploring some differences in nonverbal communication between European travellers and the natives of India and Persia, as they emerge from literary pieces written in the period 1664-1900. The focus will be on two nonverbal codes only, namely use of artefacts and rituals and practices. The analysis indicates both similarities, as well as differences between the two investigated cultures in terms of use of artefacts and rituals.
\end{abstract}

Keywords: intercultural encounters, nonverbal communication, artefacts, rituals and practices

\section{Introduction}

The urge of discovering new places has characterised mankind for ages. People have travelled to close or remote regions for various reasons: to search for food (the nomadic hunters), to conquer territories, to exploit natural resources, to trade various products, to convert pagans to Christianity, or to simply explore unknown regions as part of their education. The latter aim characterized many travellers of the Middle Ages and of early modern times, who, on their journeys to littletravelled countries, hoped to find something remarkable and interesting, worthy of being recorded in their diaries and recounted to their compatriots upon return to their homelands. This curiosity for new cultures and people opened the way to intercultural communication. In most of the cases, the barrier that hindered communication between members of different cultures was the language. Very few people during the Renaissance and the early modern period could speak foreign languages. "And even if they can speak a common language, they may misinterpret the cultural signals" (Beamer \& Varner 2008: 52). 
Language was not the only obstacle: the nonverbal signals sent by the travellers and the natives of the countries they visited could make things worse due to the fact that their meaning and interpretation depend on a number of factors. As Beamer \& Varner point out, "people from different cultures attach different meanings to nonverbal signals. As one example, in Western cultures, eye contact can signify honesty, whereas in Asian cultures it may indicate rudeness" (2008: 200). The interpretation of the nonverbal messages becomes even more complicated due to the fact that within one and the same culture the signals employed to convey them are not the same for all the people. As we shall see later on, men and women often employ different nonverbal language. Then, people belonging to different social classes within a culture may use nonverbal signals differently. Thus, in many cultures, people in power may be more assertive when communicating with members of lower classes or people in lower positions.

The general purpose of this paper is to bring to the fore some aspects that pertain to the differences in the nonworded laguage of some Western travellers (two British and one Italian) and that of the natives they encountered in the Asian countries where they lived for a period of time, namely Persia and India, and to see the extent to which the nonverbal signals employed by the Persian and the Indian people are similar or different. This will be done on the basis of an analysis of fragments excerpted from the diaries they kept and published in various forms, as it will be shown in section (4). My intention is to present the authors' nonverbal experiences as they had lived them, without passing any judgements with respect to the cultural norms and practices of the people in the Eastern part of the world.

In the next section, I will offer an overview of culture, starting with a definition and by reviewing some of its characteristics. Then, in section 3 , my attention will turn to the dimensions of culture that interfere in intercultural communication, emphasizing those elements that pertain to the nonverbal language. This will be followed by a short presentation of the books that have proven a rich source of examples of differences between the West and the East (section 4), while in section 5 some of these examples will be analysed in details. The last part of the paper will contain some conclusions.

\section{Culture}

In this section I will provide a definition of culture and some of its characteristics in order to make the idea of cultural differences more accessible to the reader, as in "encountering people who are culturally different from us, their dissimilar ways of thinking and behaving challenge our fundamental ways of experiencing" (TingToomey 1999: vii). Among specialists, there is general consensus that culture is a 
multifaceted concept, and thus, very difficult to define. Since my intention is to examine those features of culture that contribute to the perception of difference and hence influence intercultural communication, the most encompassing definition of culture I have come across was that provided by Samovar and Porter (2003: 8), according to whom culture is "the deposit of knowledge, experience, beliefs, values, attitudes, meanings, social hierarchies, religions, notions of time, roles, spatial relationships, concepts of the universe, and material objects and possessions acquired by a group of people in the course of generations through individual and group striving". This definition moves across a broad number of elements, from values and beliefs (elements that are very difficult for an outsider to perceive and understand) to material objects (that are easier to discover). This is the reason why many researchers have conceptualised culture like an iceberg:

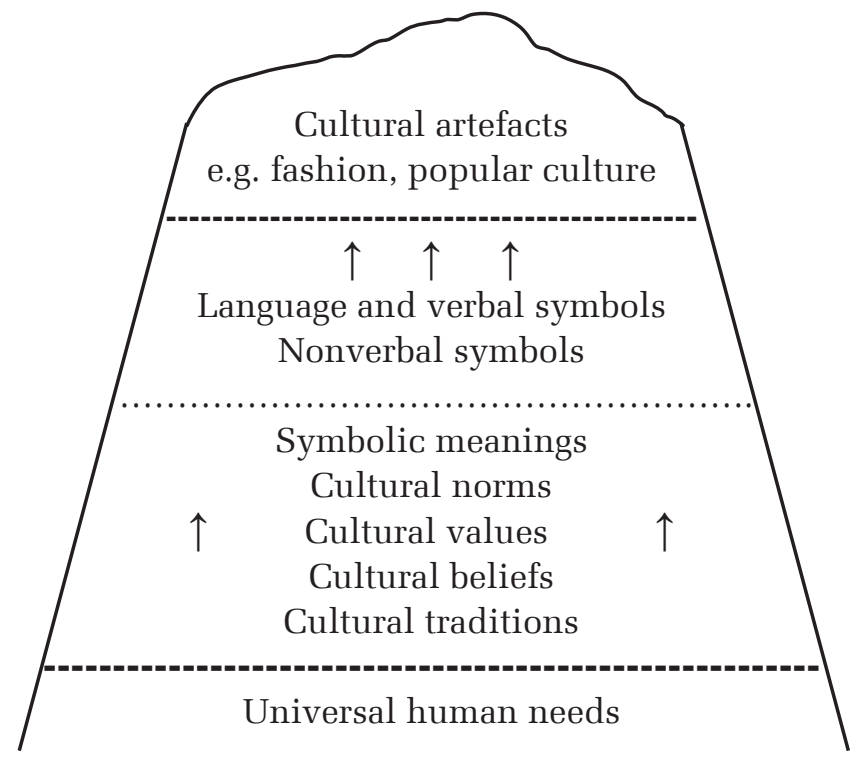

Figure 1. The iceberg metaphor of culture (Ting-Toomey 1999: 10).

As Andersen (2003: 239) points out, "culture is primarily an implicit nonverbal phenomenon because most aspects of one's culture are learned through observation and imitation rather than by explicit verbal instruction and expression. The primary level of culture is communicated implicitly, without awareness, chiefly by non-verbal means". It is exactly these nonverbal means that pose problems in intercultural encounters. The following section will briefly present them. 


\section{Nonverbal communication}

Nonverbal communication is a subtle, non-linguistic, multidimensional process which "is very much culturally rule-governed. (...) Rules dictate all of our communication behaviours, but rules are especially evident in our nonverbal communication" (Dodd 1995: 155).

Nonverbal communication is influenced by a series of factors, some of which are of a genetic nature and will lead to similarities in people's behaviour. Apart from the numerous similarities, there is an abundance of differences, which in many cases are the result of culture. "Cultural differences are not random events; they occur because cultures developed with different geographies, climates, economies, religions and histories, each exerting unique influence" (Andersen et al. 2003: 74).

A look at the major aspects of nonverbal signals will provide a better understanding of the many ways intercultural meanings are inferred. These are: body language (kinesics) which includes gestures, facial expressions, eye contact, positions of the body, ways of greeting and their relation to communication. Paralanguage (which lies between verbal and nonverbal communication) covers non-symbolic vocal sounds, such as aha or uhm employed as fillers in our conversation. Another element of nonverbal communication involves chronemics that refers to the way in which people perceive and use time. Proxemics is the language of space; it regulates how close or distant we should get to other people. Haptics or touching behaviour represents another way in which people can communicate nonverbally and which is of importance in intercultural encounters as there are certain rules in various cultures that stipulate whom to touch and when. Finally, the general term 'self-presentation' includes the physical appearance of people (height, colour of skin, etc.) and the use of artefacts. These nonverbal codes or mediums can be employed consciously (i.e. we are able to control them, in an attempt to mislead our interlocutors) or unconsciously (i.e. we cannot control them, thus our true feelings and attitudes are disclosed).

The interpretation of all these nonverbal codes may be even more complicated due to the fact that "within a culture not all people use the same signals. Men and women often use different nonverbal language. (...) People from the upper classes or people in leading positions may be more assertive with people from the lower classes and in lower positions" (Beamer \& Verner 2008: 200).

For reasons of space, in exploring the cultural differences in nonverbal communication between the Western travellers and the Persian and Indian people, I shall focus on two nonverbal aspects only: the use of artefacts and rituals/practices, as these are quite obvious in intercultural encounters. These will be analysed in details in section 5 of the paper. 


\section{A word on the corpus of literary works employed}

In order to illustrate the differences between the Western and Eastern cultures, I used a number of books written by travellers of different origins and of different epochs/centuries, who, in depicting the foreign cultures they encountered along their journeys, employed various genres. Thus, Pietro della Valle, the author of the Travels of Pietro della Valle in India (1658/[2010]), presented his encounters with the Indian culture in mid-17 $7^{\text {th }}$ century in an epistolary novel: all he experienced (whether good or evil) is recounted in letters he sends back in Italy to his advisor. These letters contain details related to religious beliefs, rituals, and use of artefacts, and represent an important source of information regarding the history of the southern part of India, more specifically of the Keladi region. Della Valle's travel to India (Persia and Turkey) was "an alternative to suicide after a failed love affair" (Introduction to the Cambridge Literary Collection, 2010: 2), though in the book he confessed a number of times that curiosity of discovering new worlds and people made him leave his homeland.

James Morier's novel, The Adventures of Hajji Baba of Isphahan (1824), provides the reader with a portrait of the late $18^{\text {th }}$-century Persian manners and life. Morier was a diplomat who spent part of his life in this Asian country and who came to an understanding of the culture of this land. This familiarity with the Persian culture allowed him to satirize the country and its people under the guise of a fictitious narrator, Hajji Baba, a Persian of the Persians. Apart from offering a view of the Persian culture, Morier's book could also be considered a historical document, as the people we read about were living personalities of the time he spent in Persia.

The third book I have used to illustrate nonverbal aspects typical of the Eastern culture (Behind the Veil in Persia and Turkish Arabia. An Account of an Englishwoman's Eight Years' Residence Amongst the Women of the East) was written by M. E. Hume-Griffith (1909), the wife of an English doctor who was sent to Persia by the Church Missionary Society to perform medical work there. As a doctor's wife, the authoress presents the usefulness of and the positive impact the Western medical practices had on the Oriental people, who originally rejected them. More importantly, her book is an accurate description of the domestic life in some important places in Persia (such as Tehran, Mosul, and Isphahan), ${ }^{1}$ as well as of Persian etiquette and various rituals. As the subtitle may suggest, much of what M. E. Hume-Griffith writes about is related to the Eastern women, "these charming, but too often unhappy followers of Mohammed" (Hume-Griffith 1909: 19), whose birth is regretted, whose death is not mourned by anyone, and whose life is comparable to that of slaves.

1 In keeping with the original title of Morier's book, have chosen to use the old spelling of this particular place. 
With these bits of information in mind, let us now turn to the differences in nonverbal communication between the West and the two Eastern countries, Persia and India, as they emerged from the aforementioned books. As mentioned previously, I shall focus on the use of artefacts and on rituals and practices and how they are perceived by the Western travellers.

\section{India and Persia through the lens of literature: a nonverbal communication approach}

The first element pertaining to nonverbal communication I will investigate is the use of artefacts. According to Borisoff \& Merrill (2003: 275), "artefacts are objects. When worn, they have been used to signify a wearer's gender, culture, and socioeconomic class". In this part of the paper, I will discuss two types of artefacts that are richly presented in the books, namely means of transportation and attire.

As far as the way in which people travelled from one place to another in the $17^{\text {th }}$ and $18^{\text {th }}$ centuries is concerned, there are many similarities between India and Persia: in both countries, it was basically people of the high social class that were carried in special vehicles and in both women could travel in a special kind of litter or panniers. But as we shall see, there are also slight differences between the two countries in terms of means of conveyance.

In Morier's Hajji Baba, Zeenab - the Kurdish maiden and Hajji's future sweetheart - tells him how her family had to run away from the Turks. In doing so, she mentions the way people used to travel in those days:

His mare, which was now become an object of the first consequence, was to be mounted by my father, in person, whilst his chief wife, with her children, were to travel in the cajaveh or panniers; the camel which was to carry them being ornamented with trappings inlaid with beads, set off by red cloth trimmings, and a thick profusion of tassels. (Morier 2007 [1824]: 168)

As this fragment shows, in $18^{\text {th }}$-century Persia, just like in most parts of the world, animals represented the main means of transportation. When travelling, Persian men used to ride horses or mules, depending on their social class and welfare, while women and children were transported in the so-called 'cajavehs', mounted on camels. Apart from giving a synonym for the Persian term ('panniers' - which were also used in Europe at the beginning of the $19^{\text {th }}$ century, though in a different form from that in Persia), Morier did not provide the reader with any additional information. We find more about the comfort and aspect of this means of transportation in Hume-Griffith's book: 
For those who do not care, or are not strong enough for riding, there are many conveyances. (...) the traveller has quite a large choice of good things. First of all, there is the "kajavah".2 This consists of two large cage-like boxes suspended one on each side of the animal: the interior of these boxes sometimes boasts of a little low seat, but as a rule is innocent of any such luxury. Two people of about the same weight should sit on each side, or the result is disastrous. (Hume-Griffith 1909: 23)

The problem that such a means of transportation poses is that the people travelling by it should be of similar (if not identical) weight, in order to preserve the centre of gravity, as the kajavah is only loosely slung over the camel's back. Any brisk movement of the travellers can cause a disaster. Hume-Griffith, in recounting the short journey of two wives in a harem by means of this 'vehicle', mentioned that as one was heavier than the other, the servants had to place stones in the pannier occupied by the skinny wife, but not even this measure helped.

If the kajavah did not appeal to the traveller,

(...) then there is the 'takhtiravan'. This is a most luxurious mode of conveyance, and is, as a rule, used only by invalids or high-class Moslem ladies. It consists of a box, with doors and windows, measuring about six or seven feet by four in length and five in height. The top is covered with heavy felt or some material which will keep out the sun or the rain, according to which season of the year you are travelling in. Inside is placed a mattress with plenty of cushions: the whole is built on shafts which are slung between two mules, one in front and one behind. (Hume-Griffith 1909: 25)

This more luxurious means of transportation, though apparently much more comfortable than the previously described one, had, nevertheless a disadvantage, too: if the road was bad or if the mules did not keep in step, a journey that promised to be comfortable may have caused the traveller bruises. Despite this, people needed to travel from one place to another: those of the lower social class rode mules, whereas the ones who were better off, employed horses. But as women had to be protected from being seen by other men than their husbands or very close family members (such as their fathers, brothers or uncles), they were quite safe in the 'comfort' of the kajaveh and takhtiravan.

The takhtiravan was very similar to the English sedan chair/litter, only that in Persia this means of conveyance was carried by mules, whereas in Europe by slaves. At the same time, a similar means of transportation seems to have been employed throughout entire Asia, acquiring different denominations depending on the country: jiao in China, gama in Korea, or palanquin in India.

2 Notice the difference is spelling of the word by the two authors. 
Pietro della Valle describes such a palanchino (as he called it), which was used in India not only to transport royal or noble ladies (like in Persia) but also men, in exceptional situations. Such a one is presented by della Valle in connection with a monk:

I saw, I say, in the Piazza one of their Fryers, or Giangami, clad all in white, sitting in an handsome Palanchino, with two great white Umbrellas ${ }^{3}$ held over him, one on each side, (which two were for the more gravity) and a Horse led behind, being follow'd by a great train of other Giangami, clad in their ordinary habits. (della Valle 2010 [1663]: 268-269)

The importance of the giangamo (friar) is highlighted by his conveyance in a palanchino and is also emphasized by the two white umbrellas (more correctly parasols) that protected him from the sunlight, the umbrella being an artefact which in the East is regarded as a mark of dignity. The use of parasols in India is also related to religion: in Buddhism, for instance, the umbrella symbolises the heaven, and is employed in many ceremonies. ${ }^{4}$

Palanquins were not only used for transporting people, but also for carrying the statues of Indian idols during various religious processions. Pietro della Valle describes in details a number of such processions he encountered along his voyage in India, but for reasons of space, only a short fragment from one of them is rendered below which, apart from the palanquin, also mentions other artefacts used in religious ceremonies, such as musical instruments and ornaments:

(...) they went forth into the street, where much people expected them, carrying two Idols in Procession, both in one Palanchino, one at each end, small and so deck'd with Flowers and other Ornaments that I could scarce know what they were. Yet I think that in the back-end was Agoresouer, to whom the Temple is dedicated, and the other Parveti or some other Wife of his. (della Valle 2010 [1663]: 279)

The second type of artefact under scrutiny is represented by clothes. Clothing is a form of artefactual communication that "manifests[s] and promotes[s] cultural definition of masculinity and feminity" (Wood 1994, quoted in Samovar \& Porter 2003: 275-276). Like other forms of non-verbal communication, the way we clothe our bodies may be interpreted to signify things that the communicator may not have intended.

3 Della Valle's book was translated into English in the Middle English period, when nouns were still capitalized. This is the reason why in all excerpts from his book most nouns are spelt with capital letters.

4 http://www.religionfacts.com/buddhism/symbols/parasol.htm 
The most striking difference concerns the garments that cover the bodies of women in India and Persia. Thus, while Persian women were supposed to cover their entire bodies and even use a veil, in Southern India of the $17^{\text {th }}$ century many of the women not only did not cover their faces, but would also wear nothing above the waist. This way of dressing, which is still common among women in Southern India at present, was (and is) very much related to the climatic conditions in that area. At the same time, this fashion did not have anything to do with the social status of women, as both commoners and the Queen of Olala adopted the same style of dressing themselves, as depicted below:

From the waist upwards the Queen was naked, saving that she had a cloth ty'd round about her Head, and hanging a little down upon her Breast and Shoulders. In brief, her aspect and habit represented rather a dirty Kitchenwench, or Laundress, than a delicate and noble Queen. (della Valle 2010 [1663]: 307)

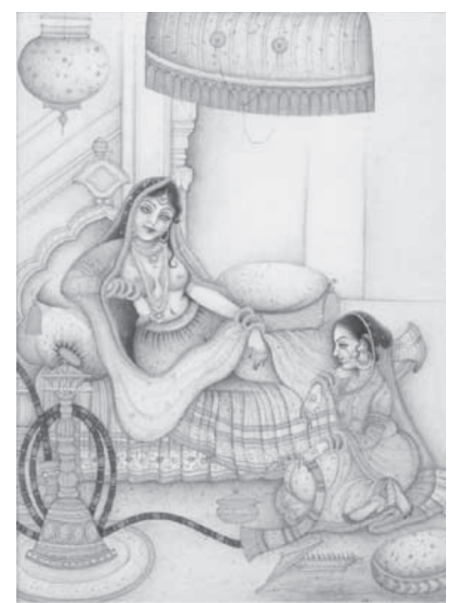

Figure 2: Women's way of dressing in South India ${ }^{5}$

By comparing the Indian Queen to an English kitchen maid, della Valle hints at the fact that in his homeland, attire was an indicator of women's status.

We can easily imagine the surprise of the Italian traveller at the sight of the nakedness of the bodies of Indian women, as he came from a country where at that time (i.e. the $17^{\text {th }}$ century) women used to have their bodies covered by long skirts/dresses and blouses. His Indian female interlocutors were equally surprised at seeing the many items of clothing della Valle was wearing, as illustrated below:

One of them, being more forward, could not contain herself, but, approaching gently towards me, almost touch'd the Sleeve of my Coat with her hand,

5 http://www.exoticindiaart.com/article/theindiansari/ - public domain. Accessed March, 2015. 
making a sign of wonder to her Sister how we could go so wrapp'd up and entangled in Clothes as we seem'd to her to be. Such is the power of Custom that just as their going naked seemed strange to us, so our being cloth'd appeared extravagant to them. (della Valle 2010 [1663]: 367)

It is not only women that were scantily clad in Southern India, but also men of all social classes, from soldiers, to priests and even to the King. They only covered their intimate parts with a cloth of cotton or linen, the rest of the body remaining naked.

The King and all others, as I have said, commonly go naked; onely they have a cloth wherewith they are girded, reaching to the mid-leg. Yet, when upon any occasion the King is minded to appear much in Majesty, he puts on onely a white vestment of very fine cotton, never using either Cloth of Gold, or Silk. Others also when they please may wear the like garment, but not in the King's presence, in which 'tis not lawful for anyone to appear otherwise than naked, saving the cloth above-mentioned. (della Valle 2010 [1663]: 370-380).

Again, we can imagine the astonishment of the Italian traveller when seeing that the Indian king was naked from the waist up, while in his country the person of the same rank would be adorned with the finest and most expensive clothes and jewels. The conclusion one can draw from della Valle's account of the Indian fashion is that both men and women would go quite naked, except for a piece of either cotton or silk "hanging down from the girdle to the knees and covering their shame” (della Valle 2010 [1663]: 360).

At the other extreme we have the Persians who did cover their bodies quite heavily and whose clothes not only indicate gender, but also social status and profession. Thus, our hero, Hajji Baba, who "advanced in station and dignity" throughout the book, starting from being a barber and rising slowly to a watercarrier, a vendor of 'smoke' (tobacco), a dervish, ${ }^{6}$ an executioner, a scribe, a doctor's servant and even a doctor, had to indicate each of the professions he held by means of appropriate clothing. Consequently, when the occasion imposed his becoming a dervish: "It was agreed that I should put on the dress of a dervish; and having made my purchases, in the bazaar, of a cap, some beads, and a goat's skin, which I slung across my shoulder, I was ready to begin my journey at a moment's warning.” (Morier 2007 [1824]: 132)

As far as women's clothes are concerned, they very seldom were indicators of a person's job, as at that time women were simply housewives. Still, at the Persian Shah's court, female jobs were also differentiated in terms of clothing. Zeenab, 
who was a slave in the Shah's harem, was ordered by the latter to become a dancer in a very short period of time. This change in her status had to be reflected by her garments: "The Shah (..) calling the chief eunuch to him, he ordered that I should be educated for a baziger (dancer or singer), that all my clothes, \&c., should be made suited to my future profession.” (Morier 2007 [1824]: 182)

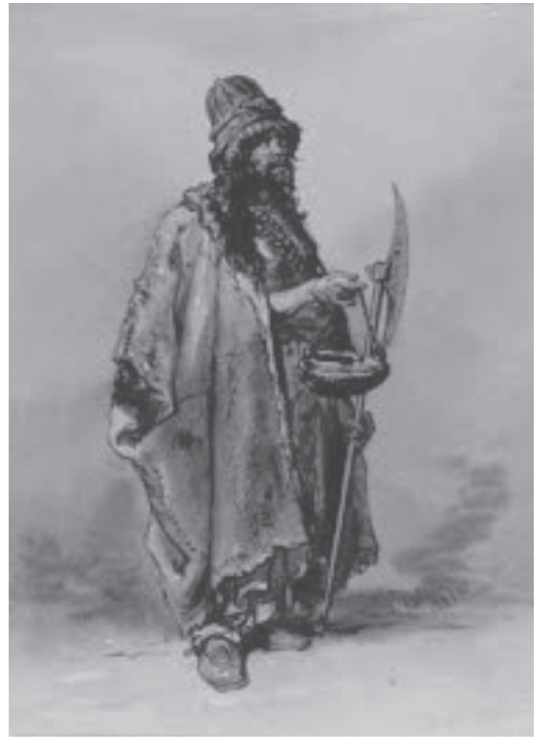

Figure 3: A Persian dervish ${ }^{7}$

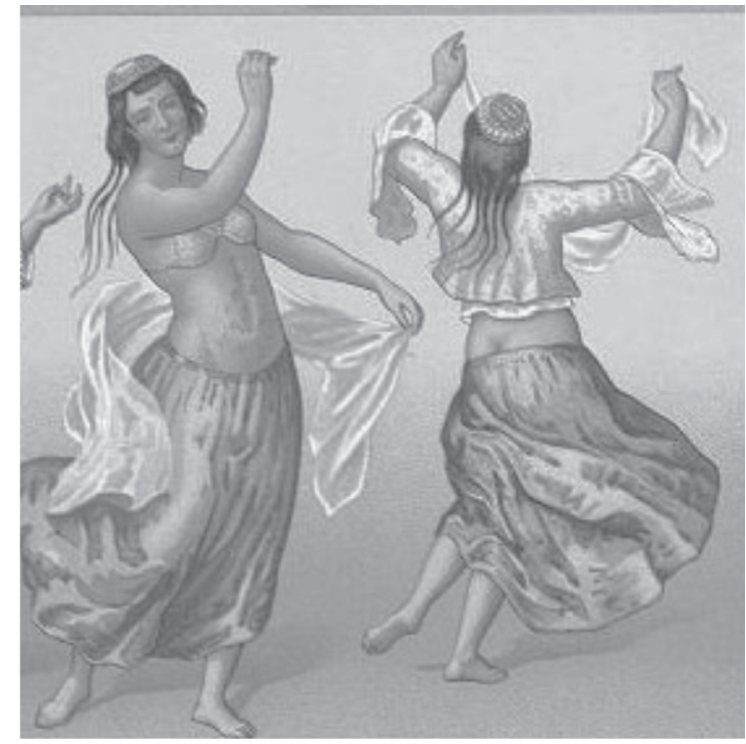

Figure 4: Dancers' costumes ${ }^{8}$

A more relevant difference is that between the clothes that Persian women wore at home and when they paid visits. A clear description of these garments is provided by Hume-Griffith. Note has to be made that there is almost a century difference between Morier's and Hume's encounters with this part of the world, a time span in which things had changed dramatically. Moreover, while the former gave us a description of the male clothes, Hume-Griffith, who had the chance of seeing Persian women both in their homes and at her own, provides us with a detailed account of their wardrobe:

The indoor costume of the Persian women is not at all pretty or graceful. It consists of a short loose jacket, generally made of some gaily coloured

$7 \quad h t t p s: / / w w w . g o o g l e . c o \cdot k r / s e a r c h ? q=a+$ persian+dervish $\&$ espv=2\&biw=1280\&bih=606\&tbm=isch $\varepsilon t b o=u \& s o u r c e=u n i v \& s a=X \& v e d=0 a h U K E w i M 0 a r F 7 \_v K A h W F g 6 Y K H Z N k D x c Q 7 A k I P g \& d p r=2$ \#imgrc=AbFDCNmGKdiz5M\%3A - public domain. Accessed March, 2015.

8 http://historyoffashiondesign.com/the-orient-persia-and-environs - public domain. Accessed January, 2015. 
material, and in the case of rich women of bright brocaded silk or velvet, and a very short skirt, just like the length of a ballet dancer's. (...) Many years ago, all the women wore those picturesque baggy trousers, with long flowing garments over them (...) On their heads they wear a square of white muslin, and flowing down their backs, and attached by a pin to their hair, is a long graceful chuddar, generally made of pretty muslin or silk; and as these women walk about the house, these chuddars flow behind and look very graceful indeed. The outdoor costume of the Persian women is much more becoming than the indoor, though it is decidedly hot in the warm weather. It is made up of three pieces: the big voluminous trousers which slip over the feet and cling closely to the shape of the foot but above the ankle fall full and baggy; over these are worn the large black chuddar, the poor wearing black calico and the rich silk; and then, covering the face, is the veil. This veil (...) is fastened together at the back of the head by brass, silver or golden and jewelled clasps, according to the rank of the wearer. (Hume-Griffith 1909: 95-97)

The fragment highlights several important things related to Persian women's costumes: first, it presents the items that make up their attire; then, it emphasises the class difference in terms of quality and beauty of materials employed to produce the clothes (slaves and servants wearing calico, while rich women silk); and thirdly, it points to the fact that once out of their homes, Persian women had to better cover their bodies, wearing longer, more protective items of clothing. By comparing this fragment with the one in which della Valle described the way South Indian women dressed, we can find a similarity: both Indian and Persian women covered their heads with long veils, only that the former did so less precariously.

It seems that the Persian women were not very happy about the short skirts they had to wear indoors, so that they would often take their long chuddars from their heads and wrap them round their waists, as if a draped skirt.

Let us now turn our attention to another means by which people of one culture can surprise or even shock persons from another culture, namely rituals and practices. Among the practices that seem to differ greatly in the West and the East are the burial ones. The burial practices and rituals are very much dependent on the climatic conditions in each area of the world, and, at the same time, are also dictated by religion. Thus, in the Islamic religion, it is customary to have the deceased buried in the ground ${ }^{9}$ as soon as possible from the time of the death. On the other hand, in the Indian culture, especially among the Hindus, the cremation of the deceased is preferred, as illustrated by the following excerpt from della Valle:

9 Cremation is forbidden in Islamic cultures (https:/www.everplans.com/articles/muslimfuneral-traditions, accessed March 12, 2015). 
Returning home, I met a corpse going to be burn'd without the City, with Drums sounding before it; it was carry'd sitting in a Chair whereunto it was ty'd that it might not fall, cloth'd in its ordinary attire, exactly as if it had been alive. The seat was covered behind and on the sides with red and other colours, I know not whether Silk or no. It was open onely before, and there the dead person was to be seen. By the company, which was small, I conjur'd him to be one of mean quality. But they told me that all people are carry'd thus, as well such as are buried (as the Lingavani, whom they also put into the earth sitting) as those that are burn'd; and that he whom I saw was to be burn'd we gather'd from the Fire and Oyle which they carry'd after him in vessels. (della Valle 2010 [1663]: 271) [10 $^{10}$

The procession described above is not at all ceremonious: the clothes worn by the deceased are ordinary, the corpse is placed on a chair (rather than in a coffin, as was common in most European countries of the time) with little ornamentation. The only sounds that accompanied the procession were those produced by the drums.

The burial practices in Persia seem to have been equally modest, in that little money was spent on clothes. But while in India people seemed to accept death with dignity and in silence, in Persia it was customary for the close relatives (and not only) to produce extremely loud lamentations and to tear their clothes.

According to Morier, at the end of the $18^{\text {th }}$ century, Muslims first washed the bodies of the deceased with cold water, then rubbed them with lime, salt, and camphor, after which they placed them in inexpensive white winding sheets. The feet of the deceased were always directed to the Kebleh (i.e. toward Mecca). The tying of the toes and the placement of the handkerchief under the chin were only meant to keep the mobile parts of the body stable, having no specific symbolism. Some of these aspects are present in the description of Hajji Baba's father below:

Water steeped in cotton was then squeezed into his mouth, his feet were carefully placed towards the Kebleh, and as soon as it was ascertained that no further hope was left, the priest at his bed-head began to read the Koran in a loud and sing-song emphasis. A handkerchief was then placed under his chin, fastened over his head, and his two great toes were also tied together. (Morier 2007 [1824]: 263)

What the reader gets from Morier's book related to burial practices is that when they die of natural causes, women and men are equal in the Islamic culture, in that the family members and friends have to produce lamentations and tear their

10 The spelling in the fragment above is true to the one in the English translation from Italian made in 1664. 
clothes. But in everyday life, among the Persians, there were different ways of punishing men and women, as we shall see in what follows.

Punishment took different forms in $17^{\text {th }}$ century Persia, depending on the gender of the wrongdoer and also on the type of crime. A very frequent and rather mild way of punishing men was the bastinado on one's feet. This procedure implied having the feet of the criminal inserted in the noose in the middle of a pole (called 'felek') held up by two persons, while two other men applied blows to the soles. Morier's character, Hajji Baba, received this kind of punishment a number of times, and he recounts the story of an acquaintance of his, mollah ${ }^{11}$ Nadân, who, due to the fact that he had attacked a Turkish convoy, was punished in a similar way: "They were not generous enough to let us off, but ordered the administration of the bastinado with a degree of religious zest that I thought could never have existed in any breast except my own. To be short, our feet were beat into a jelly." (Morier 2007 [1824]: 299).

As Morier showed throughout the entire book, the Persians treasured their beards immensely. The beard was held so sacred in the East, that every hair which grew upon a Mohammedan's chin was protected from molestation by a heavy fine. Very often, in order to appear trustworthy, the characters in the novel swore on their beards (I swear by the beard of the Prophet, p. 110, I will put my beard into your hand, p. 236, I will give him a miscal of hair from my beard, p. 271, Teez Negah is not a man to lose a hair of his beard, p. 272). Thus, to have one's beard pulled out was a very degrading punishment for a Persian male. This was the ordeal Hajji Baba's master (the hakim 'the doctor' of the Shah) had to undergo because of the fact that Hajji was the cause of the death of Zeenab, his sweetheart, who was a slave in the Shah's harem and who was also fancied by the latter. Since Zeenab dared have a relationship with Hajji and refused to marry the man chosen by her master, she was killed, which saddened the Shah to such an extent that he obliged the hakim "to make a large present to the Shah, besides having had his beard half pulled out by the roots." (Morier 2007 [1824]: 257)

The punishments applied to Persian women were crueller than those for men. In the story of how Kerman (a town in Persia) was conquered by the Moslems, M.E. Hume-Griffith showed that this was an act of treason on behalf of the daughter of the Persian king of the castle. She fell in love with an Arab general (whose army surrounded the castle) to whom she sent word that if he was going to marry her, she would deliver the castle into his hands. After the massacre that followed, in which all the inhabitants of the castle had died, the Arab general wanted to know the reason why this woman had betrayed her people. On finding out that the reason for her deed was her love for him, the general decreed that she was not a woman, but a fiend, and as such she had to die. The manner in which the poor soul found her end is described below:

11 A mollah is a Muslim learned in Islamic theology and sacred law. 
He therefore ordered his men to bind her with cords, face downwards, on to the back of a wild horse, and to turn horse and its rider into the desert. This order was carried out amidst heartrending cries and entreaties for mercy from the girl, but to all, the general paid no heed, declaring that she was only suffering a just death for the abominable behaviour to her own people. (Hume-Griffith 1909: 36)

An even more diabolical way of putting an end to a woman's life is presented in the same book. This time the victim was a woman whose husband, being angry with her for some reason, decided to get rid of her. What he did was the following:

(...) he caught a cow, and kept it shut up without water for some days. Then he bound his wife under the body of the animal and sent it off. Of course the cow made for the nearest stream, and we can imagine better than describe the fate of the poor woman. (Hume-Griffith 1909: 36)

The worst method of inflicting capital punishment that the Persians made recourse to was to wall up victims alive, irrespective of whether they were males or females. What is even more surprising is that this practice was still in use at the beginning of the $20^{\text {th }}$ century, as illustrated by M. E. Hume-Griffith:

The victim is put into a pillar, which is half-built up in readiness; then if the executioner is merciful, he will cement quickly up to the face, and death comes speedily. But sometimes, a small amount of air is allowed to permeate through the bricks, and in this case the torture is cruel and the agony prolonged. Men bricked up in this way have been heard groaning and calling for water at the end of three days. At other times, the victim is placed in the pillar head first, and in this way he is walled up. (Hume-Griffith 1909: 139)

In India, on the other hand, satī, the custom of burning the wives of deceased men was part of the demeaning of women. Our Italian traveller of the $17^{\text {th }}$ century found it cruel and barbarous, but, on the other hand, this noble selfsacrifice was worthy of praise for the women who showed conjugal fidelity and love. From della Valle's letters the reader finds out that this was an entirely voluntary act and that force was employed only when some widow was left young, beautiful, and in danger of marrying somebody else, which among the Indians was considered ignominious. The alternative to satī for a widow was, as della Valle mentioned: "to remain in continual sadness and lamentations, shave their heads and live in perpetual mourning for the deaths of their husbands." (della Valle 2010 [1663]: 276) 
In tracing the history of this ritual, Bose (2000) showed that this was actually the result of the misinterpretation of the Vedic hymns, as in the Vedic era, sati was neither approved, nor practiced. Nowadays, as a result of a law passed by the British government in India (Indira Y. Junghare, personal communication), this barbarous practice is prohibited.

The excerpts analysed above show that both in Persia and India, women were very much dependent on their husbands both in their life on earth and also in the afterlife.

Rituals, or established or prescribed procedures for religious rites, also differ in the East and West, as these parts of the world practice different religions. Thus, in Persia, the commemoration of the death of Hossein, which was religiously kept throughout the country and occasioned a festival considered to be the most sacred, is mentioned both by Morier and by Hume-Grifith. But while the former only hints at the blood which was usually shed on this occasion (my body streaming with blood, p. 122), the latter provides the reader with a detailed description of the ritual, as well as with her feelings towards the people involved in it. According to Hume-Griffith, the Passion Play or the 'tazieh' was enacted during the month of mourning (known as 'Mouhurram'), when the entire Persia mourned for Hassain and Hussein/Hossein, the martyred sons of Ali. During this period, most of the Persians go into mourning, and often the bazaars are closed and draped in black. The festival, which is held sacred, takes place on the tenth day of Mohurram. While the first part of the festival is very beautiful, in that it starts with a procession in which "gaily decorated camels" are ridden by men beating drums, the second part is quite shocking for a Westerner:

Then came a horrible sight, one which I never want to see again. About a hundred madly excited men dressed in long white robes, armed with swords, were slashing their heads until the blood was streaming down their faces on the robes, while, alas, no longer. As they reached the tank of water they formed into a line all round it, and kept up for some length of time a horrible war dance. It was a ghastly sight. The dancers looked more like demons than men. (...) The whole proceeding was an interesting but sad spectacle, which I shall never forget. The clash of swords, the beating of drums, the weird wailing of women, (...) the shouting and yelling of the fanatical mob, all contributed to the making up of the most notable scenes of Eastern life. And yet it makes one's heart ache to watch this crowd of human beings (...) take part in these gruesome religious performances. (Hume-Grifith 1909: 111-112).

Both in India and in Persia, the travellers of the past were astonished at the kissing practice of the natives of these two countries. 
As I was going along the streets to behold this Pomp, I saw many persons come with much devotion to kiss the Feet of all those Giangami, who on Foot follow'd the principal Giangamo who was in the Palanchino; and, because they were many and it took up much time to kiss the feet of them all, therefore when everyone came to do it they stood still all in a rank to give time; and, whilst such persons were kissing them and, for more reverence, touching the Feet with their Fore-heads, these Giangami stood firm with a seeming severity and without taking notice of it, as if they had been abstracted from the things of the World; just our Fryars used to do when any devout persons come out of reverence to kiss their Habit. (della Valle 2010 [1663]: 270-271)

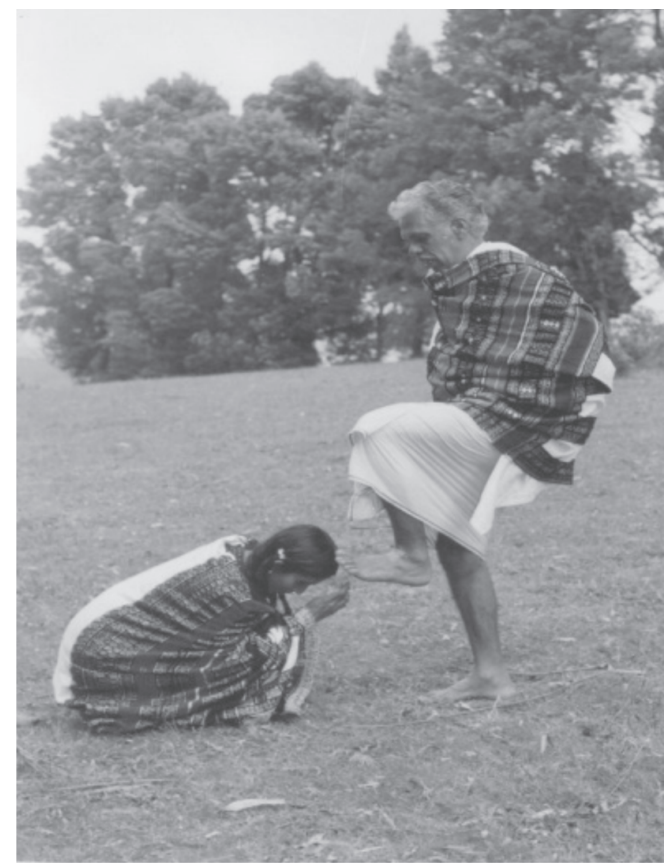

Figure 5: "Foot-kissing"12

According to Desmond Morris (1994), this practice has been in use since ancient times and lowering one's head to the feet of another person was performed by people of an inferior status as a sign of respect towards persons of higher status. Nowadays, the Toda people in South India still perform this body lowering ritual with high-status feet placed on low-status heads. In other parts of India, mothers usually touch their children's heads with their feet as some kind of blessing.

12 Print screen from The Human Animal: A Personal View of the Human Species (Desmond Morris, 1994), BBC documentary, www.youtube.com/watch?v=7qUKiHZbVwc. Accessed November, 2013. 
We encounter the same practice in Persia together with the kissing of one's knee. Just like in the Indian culture, this gesture expressed respect to people of higher ranks or authorities, but unlike in India, here it was usually performed to win various favours. "I stooped down and kissed the knee of this my new master, with every appearance of gratitude and respect.” (Morier 2007 [1824]: 106)

Among Persian men, kissing each other's lips was customary in the $18^{\text {th }}$ century. A kiss on the mouth was applied when somebody had done some outstanding deed. Thus, the Shah's poet, who had written an 'impressive' poem about a toothpick, received such an honour twice: once from the Shah himself, and a second time from the audience present at the court: "Upon which the noble of nobles, who was endowed with a large and bushy beard, approached the poet, and inflicted a kiss upon his mouth, which also was protected by an appropriate quantity of hair.” (Morier 2007 [1824]: 178)

Very frequently in his book, Morier mentioned the Persian custom of kissing the ground. The Muslim Persians did not actually touch the ground with their lips; they rather placed their foreheads or noses on the ground, expressing respect toward their God and showing humility: "Falling on my knees, and kissing the ground, I related my story in as concise a manner as possible." (Morier 2007 [1824]: 119)

Sometimes, the Persians met by Morier did not kiss body-parts of their interlocutors, but rather a certain part of their garments, namely the hem: "after having with great humility kissed the hem of the holy man's cloak." (Morier 2007 [1824]: 253). "I was so happy that I kissed the good man's hand and the hem of his garment, making him thousands of acknowledgments for his goodness." (Morier 2007 [1824]: 275)

As explained by Morier in footnote 21, if a culprit seized and kissed the skirt/ hem of a man in authority (be he a priest, the Shah or a man of the law) in Persia, he would benefit from protection from that person, just like the precincts of the church offer protection in the Roman Catholic countries.

\section{Conclusions}

The three authors, whose work has been employed in this paper, could be considered pioneers in intercultural communication. It was people like them who provided knowledge about other cultures and who opened the path to intercultural communication. While initial research in intercultural communication was based on diaries, letters, and anecdotes of individual travellers, nowadays studies are carried out on larger amounts of data that are subjected to analysis from various perspectives (anthropological, sociological, psychological, and nonverbal) in order to provide people who have to travel for various reasons with basic 
knowledge about the cultures they are going to encounter. With the multitude of information technologies available nowadays, the individuals' uncertainty about or fear of other cultures is diminished by reading or watching documentaries about these cultures and by investigating materials produced by members of the other cultural group. Interpersonal and intercultural communication in the future will be more and more meditated by computers. "Technologies such as the World Wide Web will continue to serve as channels to bring together people of diverse cultural backgrounds" (Barnett, Choon, \& Rosen 2000, quoted in Barnett \& Lee 2003: 260).

Nowadays, the process of globalisation is stronger than ever: larger groups of people cross borders for a wider range of purposes than before. Thus, there are millions of immigrants and refugees who seek a better life, their relocation being a long-term one. On the other hand, there are musicians, artists, professors, diplomats, researchers, military personnel, medical staff, and journalists whose stay in new cultures may be a short-term one. Irrespective of the length of their immersion in the new culture, for these people becoming an intercultural communicator seems to be a must. This presupposes first and foremost openness to meeting and interacting with people of different cultural backgrounds. Secondly, people who have to communicate interculturally need to adopt an attitude of mutual respect and trust and give up ethnocentrism. As Ting-Toomey puts it, the key to becoming intercultural communicators "is to prepare ourselves with competent knowledge and skills, so that we can enjoy this eye-opening intercultural learning journey" (1999: vii). Moreover, this preparation for intercultural communication should be a lifelong endeavour, because intercultural encounters are part of our lives.

\section{References}

Andersen, Peter A. 2003. Different Dimensions: Nonverbal Communication and Culture. In: Samovar, Larry \& Porter, Richard E. (eds.), Intercultural Communication. A Reader. 10 ${ }^{\text {th }}$ edition, 239-252. Australia, UK \& USA: Thomson Wadsworth.

Andersen, Peter, A., Michael L. Hecht, Gregory D. Hoobler, \& Maya Smallwood. 2003. Nonverbal Communication Across Cultures. In Gudykunst, William B. (ed.), Cross-Cultural and Intercultural Communication, 73-90. London \& New Delhi: Sage Publications.

Barnett, George A. \& Lee, Meihua. 2003. Issues in Intercultural Communication. In Gudykunst, William B. (ed.), Cross-Cultural and Intercultural Communication, 259-274. London \& New Delhi: Sage Publications.

Beamer, Linda \& Iris Varner. 2008. Intercultural Communication in the Workplace. $4^{\text {th }}$ edition. New York, Milan, New Delhi: McGraw-Hill. 
Borisoff, Deborah \& Lisa Merrill. 2003. Gender and Nonverbal Communication. In Samovar, Larry \& Porter, Richard E. (eds.), Intercultural Communication. A Reader. $10^{\text {th }}$ edition, 269-278. Australia, UK \& USA: Thomson Wadsworth. Bose, Mandakranta (ed.). 2000. Faces of the Feminine in Ancient, Medieval, and Modern India. New York \& Oxford: Oxford University Press.

Dodd, Carley H. 1995. Dynamics of Intercultural Communication. Madison, Wisconsin \& Dubuque, Iowa: WCB Brown \& Benchmark Publishers.

Hume-Griffith, E. M. 1909. Behind the Veil in Persia and Turkish Arabia. London: Seeley \& Co. Ltd.

Della Valle, Pietro. 2010 [1663]. Travels of Pietro della Valle in India (English translation 1664, edited by Edward Grey). Cambridge Library Collection. Cambridge: Cambridge University Press.

Morier, James. 1824/[2007-EBook \#21331]. The Adventures of Hajji Baba of Isphahan. eBook or online at www.gutenberg.org.

Morris, Desmond. 1994. The Human Animal: A Personal View of the Human Species. BBC documentary, <www.youtube.com/watch?v=7qUKiHZbVwc> (November, 2013)

Ting-Toomey, Stella. 1999. Communication across Cultures. New York, London: The Guildford Press.

\section{Websites}

http://historyoffashiondesign.com/the-orient-persia-and-environs, accessed January, 2015.

https://www.everplans.com/articles/muslim-funeral-traditions, accessed February, 2015.

http://www.exoticindiaart.com/article/theindiansari/, accessed March, 2015.

https://www.google.co.kr/search?q=a+persian+dervish\&espv=2\&biw=1280\&bih $=606 \& \mathrm{tbm}=\mathrm{isch} \& \mathrm{tbo}=\mathrm{u} \&$ source $=$ univ\&sa $=\mathrm{X} \& \mathrm{ved}=0 \mathrm{ahUKEwiM0arF7} \mathrm{vKAhW}$ Fg6YKHZNkDxcQ7AkIPg\&dpr=2\#imgrc=AbFDCNmGKdiz5M\%3A, accessed March, 2015. 